\title{
A Case of Familial Mediterranean Fever After Renal Transplantation: From Phenotype II to I
}

\author{
Renal Transplantasyon Sonrası Ailesel Akdeniz Ateşi Olgusu: Fenotip II’den I'e \\ Yalçın SOLAK, ${ }^{1}$ Hüseyin ATALAY, ${ }^{1}$ İlker POLAT,, Zeynep BIYIK, ${ }^{1}$ Abduzhappar GAIPOV, \\ Adem KÜÇÜK, ${ }^{3}$ Süleyman TÜRK ${ }^{1}$ \\ ${ }^{1}$ Department of Nephrology, Medical Faculty of Selçuk University, Konya, Turkey; \\ ${ }^{2}$ Department of Internal Medicine, Medical Faculty of Selçuk University, Konya, Turkey; \\ ${ }^{3}$ Department of Rheumatology, Medical Faculty of Selçuk University, Konya, Turkey
}

Familial Mediterranean fever (FMF) is the prototype of autoinflammatory syndromes. Several factors may trigger the disease including physical and emotional stress, fatrich diet, and menstruel cycle. Infections and some drugs such as cisplatin may result in a change in cytokine levels and may precipitate attacks. Most cases of FMF presents with typical self-limited attacks including fever and abdominal pain. However, a minority of patients, called as phenotype II, presents with amyloidosis AA-type and/or end-stage renal disease in the absence of clinically recognizable attacks. Immunosupression may precipitate a typical FMF attack, possibly through a change in cytokine balance. Initiation of colchicine treatment in these patients is of utmost importance to prevent amyloidosis involvement of the newly transplanted graft. In this article, we present a rare case of FMF who transformed from phenotype II to phenotype I after renal transplantation, most probably due to the effect of immunosuppressants.

Key words: Familial Mediterranean Fever; immunosuppression; phenotype I; phenotype II; renal transplantation.

Familial Mediterranean fever (FMF) is the prototype of autoinflammatory syndromes characterized by recurrent fever and serositis attacks which resolve spontaneously within 72 hours. $^{[1]}$ Some triggering factors are held responsible for the development of these attacks, for example physical and emotional
Ailesel Akdeniz ateşi (AAA), otoinflamatuvar sendromların bir prototipidir. Fiziksel ve duygusal stres, yağdan zengin beslenme ve menstrüel siklus gibi çeşitli faktörler hastalığı tetikleyebilir. Enfeksiyonlar ve cisplatin gibi bazı ilaçlar, sitokin düzeylerinde değişikliğe yol açarak ataklara zemin hazırlayabilir. Ailesel Akdeniz Ateşi hastalarının birçoğu, ateş ve karın ağrısı ile birlikte kendi kendini sınırlayan tipik ataklar ile başvurur. Bununla birlikte, fenotip II olarak adlandırılan küçük bir hasta grubu, tipik klinik atakların yokluğunda AA tip amiloidoz veya son dönem böbrek yetmezliği ile seyredebilir. Muhtemelen sitokin dengesinde bir değişiklik ile immünsüpresyon tipik bir AAA atağına zemin hazırlayabilir. Bu hastalarda kolşisin tedavisine başlanması, yeni nakledilen greftte amiloidoz gelişiminin önlenmesi için büyük öneme haizdir. Bu yazıda, renal transplantasyon sonrasında muhtemelen immünsüpresanların etkisi nedeniyle, fenotip II'den fenotip l'e geçen nadir bir AAA olgusu sunuldu.

Anahtar sözcükler: Ailesel Akdeniz ateşi; immünsüpresyon; fenotip I; fenotip II; renal transplantasyon.

stress, exposure to cold, fat-rich meals, some drugs such as cisplatin, nonspecific infections, and the menstrual cycle. ${ }^{[2]}$ Familial Mediterranean fever most commonly presents with typical attacks involving fever, abdominal pain, and sometimes a rash. ${ }^{[3]}$ Here we describe a rare patient who had a long subclinical 
FMF which was diagnosed 18 months after renal transplantation. The FMF attacks were most likely precipitated by immunosuppression.

\section{CASE REPORT}

A 44-year-old female underwent living-related kidney transplantation in September 2007. The patient had been diagnosed with end-stage renal disease (ESRD) of an unknown cause three years before the transplantation when she was undergoing hemodialysis. She had bilateral small and contracted kidneys on a renal ultrasound, and the underlying reason for her renal failure was unknown. She did not have diabetes mellitus, hypertension, renal stone disease, or frequent pyelonephritis episodes before the diagnosis of chronic kidney disease. Her family history, in terms of FMF and hereditery kidney disease, was unremarkable. She did not describe any typical FMF attacks, which usually are comprised of severe generalized abdominal pain lasting from 48 to 72 hours with a high fever. She also reported no arthralgia, pleuritis episodes, chronic diarrhea, or spontaneous skin ecchymoses or rash. The transplantation surgery and immediate postoperative period were uneventful. She was doing well with a triple immunosuppressive regimen with tacrolimus, mycophenolate mofetil, and prednisone. However, the patient was experiencing vague generalized abdominal pain without a concurrent fever once every few months after the transplantation. Laboratory and radiological examinations did not yield a possible explanation for the abdominal pain. Her erythrocyte sedimentation rate (ESR) and serum C-reactive protein (CRP) values were within normal limits, and she had no proteinuria. Suspecting FMF, we ordered genetic testing which revealed homozygous M680I mutation of the Mediterranean fever (MEFV) gene. She was begun on $0.5 \mathrm{mg}$ colchicine two times per day after which she experienced no abdominal pain for more than a year. We also performed a rectal biopsy that revealed no AA-type amiloid deposition after the diagnosis of FMF was made according to the MEFV gene findings.

\section{DISCUSSION}

Typical attacks of FMF are seen before the age of 20 in almost all patients and tend to decrease thereafter. However, in a minority of patients, called phenotype II, subclinical inflammation continues without typical attacks and culminates in AA-type renal amyloidosis. ${ }^{[4]}$ This phenotype usually affects males. It has also been demonstrated that patients with homozygous M680I mutation have more severe clinical disease than those with other types of mutation. ${ }^{[5]}$ Our patient was unusual in that she developed her first clinically recognizable attack at the age of 44 after renal transplantation. Despite her M680I mutation, she experienced a long subclinical disease, most probably in the form of phenotype II. One interesting point was that the rectal biopsy did not reveal the presence of AA-type amyloidosis. However, since she had bilaterally contracted kidneys, we did not performed a renal biopsy. This case was quite different from the classical picture in which patients with FMF usually have profound proteinuria, hypoalbuminemia, and symptomatic nephrotic syndrome along with normal-sized or enlarged kidneys. She had reported no chronic diarrhea, heart failure symptoms, anasarca edema, or nephrotic syndrome throughout the course of her disease.

To the best of our knowledge, there is only one other report describing symptomatic FMF after renal transplantation. ${ }^{[6]}$ The authors chronicled a 35 -year-old female who underwent renal transplantation due to lupus nephritis. Some differences from our patient were evident. In that case, the FMF presented solely as a fever. In addition, the primary kidney disease was lupus nephritis, and the immunosuppressive regimen included cyclosporine, azathioprine, and prednisolone. Furthermore, that patient had a positive family history for FMF. Lastly, the FMF presented one month after renal transplantation as compared with the $30^{\text {th }}$ month in our patient, and there was no report of amyloidosis. The authors implicated that immunosuppressive therapy was a potential precipitator of the FMF attacks in that patient. Sasaki et al. ${ }^{[7]}$ reported another case in which a 19-year-old male was administered cyclosporine because of myelodysplastic syndrome (MDS). The presenting features of this patient were a sudden onset of abdominal pain, fever, and diarrhea, all of which were responsive to colchicine treatment, and the authors suggested the cyclosporine treatment as the initiator of the FMF attacks. The latter patient was heterozygous for the MEFV gene, whereas the first patient did not have a genetic study. One difference from these two cases was that our patient used tacrolimus instead of cyclosporine. Our patient did not have any of the commonly mentioned triggering factors for attack development. However, changes in her inflammatory status may have somehow caused atypical attacks presenting as generalized abdominal pain despite a relatively long period after the initiation of immunosuppressive therapy. Among rare precipitators of FMF attacks, Toubi et al. ${ }^{[8]}$ reported precipitation of a colchicine-resistant attack in a patient who was 
being treated with cisplatin for lung adenocarcinoma. The authors hypothesized that the cisplatin treatment gave rise to an increase in interleukin (IL)-1, IL-6, IL-8 and tumor necrosis factor-alpha (TNF- $\alpha$ ) levels which subsequently triggered the FMF attack.

Recent studies have shed some light on the precise physiopathology of FMF. Familial Mediterranean fever patients have an increased level of inflammation, even between the attacks. The mutated pyrin protein may play a role in the regulation of cytokines, for instance IL-1b and TNF- $\alpha$ transcription factors such as as nuclear factor-kappa B (NF- $\kappa)$, kinases such as mitogen-activated protein kinase (MAPK), and leukocyte apoptosis. ${ }^{[9]}$ Cyclosporine and tacrolimus have inhibitory effects on T-helper lymphocyte production of IL-2, IL-2 receptors (IL-2r), and interferon gamma $(\mathrm{IFN}-\gamma)$ as well as to a lesser degree on the production of other cytokines (IL-3, 4 and 5, TNF- $\alpha$ and $\beta$ ) that lead to altered T-lymphocyte and B-lymphocyte function. ${ }^{[10]}$ However, some studies have suggested that calcineurin inhibitors can cause a paradoxical increase in some inflammatory markers, particularly TNF- $a^{[10-11]}$ We speculate that tacrolimus may have caused a change which produced a new equilibrium in the inflammatory cytokines and that this change precipitated the overt FMF attacks. However, no report exists describing the symptomatic deterioration of FMF patients who underwent renal transplantation and were treated with calcineurin inhibitors. This may be due to continued treatment with colchicine after transplantation to prevent the development of amyloidosis in the renal allograft. Since pyrin and NF- $\kappa$ B have many broad interaction profiles with many molecules, this precipitated attack may have been due to an interaction which has yet to be elucidated. ${ }^{[12]}$

Evidence suggests that in the absence of colchicine treatment, recurrent amyloid deposition in the allograft kidney is inevitable. ${ }^{[13]}$ The most important longterm complication of FMF is AA-type amyloidosis. In Turkey, as in other Mediterranean countries, the most common cause of this condition is FMF. ${ }^{[14]}$ Reports regarding the prognosis of FMF patients after renal transplantation are scarce in the literature. Livneh et al. ${ }^{[13]}$ showed that colchicine administration after renal transplantation successfully prevented the development of amyloidosis in the renal allograft. Interestingly, they found that $1.5 \mathrm{mg} /$ day was effective in the prevention of renal amyloidosis, whereas $0.5 \mathrm{mg} /$ day was ineffective. In untreated cases of FMF, renal amyloidosis develops first and is followed by nephrotic syndrome. The kidneys of these patients are of normal size or are slightly enlarged most of the time. The presence of small contracted kidneys, cardiac disease, chronic diarrhea, typical FMF attacks, a family history of FMF, or the absence of any personal history of nephrotic syndrome may necessitate missed diagnoses of amyloidosis and nephrotic syndrome prior to renal transplantation. Many patients currently on renal replacement therapies do not know their underlying original disease, which may have important implications after renal transplantation in terms of disease recurrence. ${ }^{[15]}$ Thus, in our opinion, even in the absence of clear-cut clinical and labaratory findings suggesting FMF and/or amyloidosis, ESRD patients with an unknown primary disease who have scheduled a renal transplantation should be evaluated with a mutation analysis and/or a rectal biopsy, especially in countries where the incidence rates of both ESRD with an unknown primary disease and FMF are high. Once detected, the diagnosis of FMF and/or amyloidosis should not deter the decision to perform renal transplantation but rather should encourage the initiation of colchicine in a timely fashion to prevent involvement of the newly transplanted kidney.

In conclusion, this case illustrates a phenotypic shift in a renal transplant patient with unrecognized FMF and secondary AA amyloidosis possibly due to the newly established equilibrium in various cytokines with ongoing immunosuppression.

\section{Declaration of conflicting interests}

The authors declared no conflicts of interest with respect to the authorship and/or publication of this article.

\section{Funding}

The authors received no financial support for the research and/or authorship of this article.

\section{REFERENCES}

1. Fonnesu C, Cerquaglia C, Giovinale M, Curigliano V, Verrecchia E, de Socio G, et al. Familial Mediterranean Fever: a review for clinical management. Joint Bone Spine 2009;76:227-33.

2. Onen F. Familial Mediterranean fever. Rheumatol Int 2006;26:489-96.

3. Masatlioglu S, Dulundu E, Gogus F, Hatemi G, Ozdogan $\mathrm{H}$. The frequency of familial Mediterranean fever in an emergency unit. Clin Exp Rheumatol 2011;29(4 Suppl 67):S44-6.

4. Melikoğlu M, Ozdoğan H, Korkmaz C, Kasapçopur $\mathrm{O}$, Arisoy N, Akkuş S, et al. A survey of phenotype II in familial Mediterranean fever. Ann Rheum Dis 2000;59:910-3. 
5. Albayrak F, Selcuk NY, Odabas AR, Cetinkaya R, Pirim I. Genotype-phenotype correlation in patients with familial Mediterranean fever in East Anatolia (Turkey). Genet Test Mol Biomarkers 2010;14:325-8.

6. Khosroshahi HT, Tubbs RS, Shoja MM. Familial Mediterranean fever triggered by renal transplantation. Nephrol Dial Transplant 2006;21:3000-1.

7. Sasaki K, Tahara T, Mitani K. Presentation of familial Mediterranean fever in a heterozygous MEFV mutation triggered by immunosuppressive therapy for myelodysplastic syndrome. Int J Hematol 2009;90:91-3.

8. Toubi E, Gershoni-Baruch R, Kuten A. Cisplatin treatment triggers familial Mediterranean fever attacks. Tumori 2003;89:80-1.

9. Haddad JJ. The role of inflammatory cytokines and NF-kappaB/MAPK signaling pathways in the evolution of familial Mediterranean fever: current clinical perspectives and potential therapeutic approaches. Cell Immunol 2009;260:6-13.

10. Rafiee P, Johnson CP, Li MS, Ogawa H, Heidemann J, Fisher PJ, et al. Cyclosporine A enhances leukocyte binding by human intestinal microvascular endothelial cells through inhibition of p38 MAPK and iNOS.
Paradoxical proinflammatory effect on the microvascular endothelium. J Biol Chem 2002;277:35605-15.

11. Kobayashi T, Momoi Y, Iwasaki T. Cyclosporine A inhibits the mRNA expressions of IL-2, IL-4 and IFN-gamma, but not TNF-alpha, in canine mononuclear cells. J Vet Med Sci 2007;69:887-92.

12. Chae JJ, Wood G, Richard K, Jaffe H, Colburn NT, Masters SL, et al. The familial Mediterranean fever protein, pyrin, is cleaved by caspase- 1 and activates NF-kappaB through its N-terminal fragment. Blood 2008;112:1794-803.

13. Livneh A, Zemer D, Siegal B, Laor A, Sohar E, Pras M. Colchicine prevents kidney transplant amyloidosis in familial Mediterranean fever. Nephron 1992;60:418-22.

14. Yildiz A, Akkaya V, Kiliçaslan I, Türkmen A, Görçin B, Atilgan D, et al. Cardiac and intestinal amyloidosis in a renal transplant recipient with familial Mediterranean fever. J Nephrol 2001;14:125-7.

15. National Hemodialysis, Transplantation and Nephrology Registry Report of Turkey, Registry 2009 [database on the Internet]. The Turkish Society of Nephrology. İstanbul 2010. Available from: http://www.tsn.org.tr/folders/file/ tsn_registry_2009.pdf 